\title{
Understanding post-Crisis Price Deviations in Europe: Disintegration or Mere Adjustment?
}

\author{
Marina Glushenkova * \\ University of Nottingham Ningbo China
}

\author{
Marios Zachariadis ${ }^{\dagger}$ \\ University of Cyprus
}

September 3, 2018

\begin{abstract}
The paper investigates the process of European integration using Law of One Price (LOP) deviations for a large number of individual goods and services during the recent Crisis. We find that the degree of integration of Eurozone economies continued to increase during this period. Importantly, we trace the location of individual goods in the distribution of LOP deviations so as to understand how price advantage or disadvantage has evolved or persisted during the Crisis. We find that rigidities rendering prices in some markets higher persisted during the same period. Thus, while well-deserved policy emphasis has been placed by the Eurozone on correcting fiscal imbalances and on monetary policy to address the resulting deflationary bias, our work suggests that little has been done in practice to break structural rigidities in goods and services markets during the period under study. Finally, comparing the distributions of LOP deviations for each of the Eurozone economies, we show that to the extent that there was adjustment for some of these economies this did not occur via the same channels for all Eurozone countries, suggesting different non-tradeables and tradeables adjustment mechanisms being in place in different countries.
\end{abstract}

Keywords: micro prices, law-of-one-price, euro, integration.

\section{JEL Classification: F4}

* Marina Glushenkova, University of Nottingham Ningbo China, 199 Taikang East Road, 315100 Ningbo, PR China. Phone\#: 86-574-88180000 (ext.8420), Fax\#: 86-574-88180125. E-mail: marina.glushenkova@nottingham.edu.cn

${ }^{\dagger}$ Marios Zachariadis, Department of Economics, University of Cyprus, 1678 Nicosia, Cyprus. E-mail: zachariadis@ucy.ac.cy 


\section{Introduction}

Law-of-one-price deviations can indicate the degree of market integration present across any two locations at a point in time. Moreover, the extent to which these persist over time can indicate persistent production characteristics or rigidities that render some locations persistently more expensive than others for particular goods and services. These rigidities could be related to market structure and in particular to the lack of competition in some of these economies 1

A large body of papers has focused on measuring the changing degree of integration in the Eurozone using micro prices. Some of these papers focus on specific markets e.g. TV set prices (Imbs, et al. 2010) or washing machine prices (Fischer, 2012) while others consider product-level prices for a broad range of tradeable goods. The latter paper does not find price convergence in the EMU for highly comparable washing machine prices during 1995-2005, while the former paper shows that EMU countries display lower price dispersion but not necessarily because of the single currency. The difference in the results could be due to differences in the markets each of these papers focuses on. Similarly, Parsley and Wei (2008) using a narrow set of comparable product items found little effect of the introduction of the euro for price level convergence in twenty-five European countries between 1993 and 2005. On the other hand, Allington et al. (2005) find increasing integration in the form of price convergence for tradeables among EMU members between 1995 and 2002 based on the analysis of price level indices for individual consumption expenditure in 200 product groups. Differences in the period and country sample under study might drive the differences in results reported in the above papers. Finally, Guerreiro and Mignon (2013) use comparative price levels for twelve EZ members at the monthly frequency between January 1970 and July 2011, and

\footnotetext{
${ }^{1}$ Rigidities could also arise due to transactions costs in international arbitrage due to market frictions (Dixit (1989), Krugman (1989)), or costs associated with preferences and technology (O'Connell and Wei (2002)), and constraints due to laws, regulations and institutions (e.g., Brock and Hommes (1997)).
} 
find high convergence speeds relative to Germany for core EZ countries but also for some of the periphery (Greece and Portugal) albeit mainly due to the latter's loss of price competitiveness.

Our results provide lower-frequency and cross-sectional microeconomic evidence in relation to the above for the periphery as well as other Eurozone countries during the Crisis years. Our paper complements previous work using European disaggregated prices, by focusing on the period between 2005 and 2014 in an attempt to understand the impact of the recent Eurozone Crisis on European integration. Part of our contribution is to investigate price integration in the Eurozone using LOP deviations for a large number of individual consumer goods and services rather than focusing on a specific market or narrow set of goods.

In previous work (Glushenkova and Zachariadis, 2016), we have shown that the distributions of law-of-one-price (LOP) deviations before and after the euro are significantly different, with density functions characterized by a higher degree of integration as implied by higher peakedness and lower cross-country dispersion after euro adoption. In the current paper, we compare micro prices around 2014 with prices in 2005 in order to understand how the Crisis might have affected the abovedescribed process of European integration. We observe that the distributions of LOP deviations after as compared to before the incidence of the Crisis are not significantly different for Greece, Portugal, Spain and other Eurozone (EZ) economies. At the same time, for the 19 EZ economies as a whole, mean dispersion fell from 0.327 in 2005 to 0.279 in 2014 implying a higher degree of market integration. This is a considerable drop in mean dispersion for the nineteen EZ economies, and comparable to the drop in dispersion from 0.303 in 1990 to 0.253 in 2005 (Glushenkova and Zachariadis, 2016, Table 7) for the thirteen early EU entrants over a longer period of time that involved the preparation for and eventual completion of European monetary unification for all but two of these countries. 
Importantly, we trace the location of individual goods in the LOP distribution so as to understand how price advantage or disadvantage has evolved or persisted during the recent Crisis. In Glushenkova and Zachariadis (2016), we showed that the location of individual goods' prices in the distribution of LOP deviations persists for decades and that price advantage appears to be more persistent than price disadvantage consistent with a persistent productivity advantage for countries like Germany, the Netherlands and the UK. If the Crisis had an impact on long-standing rigidities across EU countries, then we would have observed a considerable fall in persistence over the past few years for goods that had been consistently more expensive in some of the more problematic economies. We find that this is not the case. In particular, persistence ${ }^{2}$ for goods that were more expensive is typically high and comparable for 2010-2014 and 2005-2010 in Cyprus, Greece, Ireland, Italy, Portugal, Spain and elsewhere in Europe, suggesting that any pre-existing rigidities remained in place during the Crisis.

To the extent that there was price adjustment in some of these economies this did not occur via the same channels for all of these economies, implying that different non-tradeables and tradeables adjustment mechanisms were at place in each economy $]^{3}$ More specifically, both the mean and median non-tradeable product price fell relative to other EZ economies in Cyprus and Greece consistent with significant downward income adjustment there relative to other EZ economies. However, there was only a small fall in relative prices for non-tradeables in Ireland, Portugal and Spain, despite large relative drops in income in all three of these countries. A relative fall in the price of non-tradeables was also observed in Austria, Germany, France, Iceland and the UK, and was associated with a relative fall in income during the period for the last three countries. During the same period, both the mean and median tradeable good price fell in Cyprus, Iceland, Ireland,

\footnotetext{
${ }^{2}$ Defined as in Glushenkova and Zachariadis (2016) as the percentage of goods which remain on the same side of the distribution (in this case, above zero thus more expensive) for the pair of years being compared in each case.

${ }^{3}$ The importance of traded and non-traded inputs has been emphasized, for example, by Parsley and Wei (2007, 2008), Faber and Stockman (2009), Lee and Shin (2010), and Lee (2010).
} 
Italy and the UK. Downward price adjustment in locations that were initially more expensive for tradeables like these five countries, is a sign of further integration of these economies with the EZ. A small relative fall in tradeables prices was also observed in Portugal and Spain but not for Greece, reflecting the perceived price inelastic nature of product markets in this case.

The next section describes the data, while the following section provides our empirical methodology and results. The final section briefly concludes.

\section{Data}

We define LOP deviations as

$$
q_{i j t}=\ln \left(p_{i j t}\right)-\sum_{j=1}^{N_{i t}} \ln \left(p_{i j t}\right) / N_{i t}
$$

where $p_{i j}$ is the price of good $i$ in country $j$ at time $t$, expressed in Euro, and $N_{i t}$ is the number of EZ economies where good $i$ is available at time $t$. We regard LOP comparisons relative to the EZ-19 mean price. The EZ-19 are the nineteen EZ economies as of January 1st 2016.

The retail price data utilized here originate from Eurostat surveys conducted across European cities sampled in 2005, 2010 and 2014. The level of detail goes down to the level of the same brand sampled across locations, enabling highly accurate comparisons across space at a given point in time. The specificity of the goods is described in detail in Crucini, Telmer, and Zachariadis (2005). Similar data for earlier sets of periods are used in Inanc and Zachariadis (2012), ending in 1990, and Glushenkova and Zachariadis (2016), ending in 2010. The price data for each crosssection is collected in a sequence of surveys where the same group of goods is collected within the same sub-period for all countries. The Eurostat survey covers 31 countries for 2505 goods in 2005,37 countries for 2414 goods in 2010, and 37 countries for 2139 goods in 2014 . The 31 countries available in 2005-2014 include 19 Eurozone countries (Austria, Belgium, Cyprus, Estonia, 
Finland, France, Germany, Greece, Ireland, Italy, Latvia, Lithuania, Luxembourg, Malta, the Netherlands, Portugal, the Slovak Republic, Slovenia, and Spain), non-EZ EU countries (Bulgaria, Czech Republic, Denmark, Hungary, Poland, Romania, Sweden, and the UK) and other European countries (Iceland, Norway, Turkey, and Switzerland).

The Eurostat survey reports retail prices paid by a customer at the point of sale and therefore include value-added tax. We have collected data on VAT rates for various product categories from the European Commission report on VAT Rates Applied in the Member States of the European Union ${ }^{4}$ for 2005, 2010, and 2014, and applied these category/year-specific VAT rates to obtain free of value-added tax price of each product. In what follows, we present the results for prices net of VAT.

We constructed our panel dataset from the separate cross-sections data via the painstaking task of matching goods available in the 2005, 2010 and 2014 cross-sections. We focus on goods that were available for both 2005 and 2014. In what follows, we mostly focus on these two years since they more clearly mark the period before and after the incidence of the Crisis. Moreover, because for 2005 and 2014 we have additional information in the form of specific brand names (see Table 1 for a representative subset of all goods) not available in 2010. This allows for a much more careful matching across years than was possible in Glushenkova and Zachariadis (2016). The matched goods prices were adjusted to have the same quantity units in different years, using an appropriate adjustment coefficient. To explain LOP deviations across European countries we use only goods with sufficient cross-country variation. This is taken to be at least sixteen observations. Furthermore, to alleviate measurement error, we control for outliers by eliminating observations that are at least ten times bigger or smaller than the cross-country mean price level.

\footnotetext{
${ }^{4}$ Available at https://circabc.europa.eu/faces/jsp/extension/wai/navigation/container.jsp
} 


\section{Empirical results}

In Table 2, we report the average $q_{j t}$ for each country $j$ for goods that can be broadly categorized as traded versus non-traded. In the first two columns of Table 2, we present the deviation of nominal income in euro for each country relative to the EZ19 in 2005 and 2014. Nominal income is measured as gross domestic product in current prices divided by midyear population, available from the World

Bank WDI database. We define income deviations as $\Delta g d p_{j t}=\ln \left(g d p_{j t}\right)-\frac{1}{N} \sum_{j=1}^{N} \ln \left(g d p_{j t}\right)$, where $N$ is the number of (nineteen) EZ economies.

As we can see in Table 2, both the mean and median non-tradeable product price fell relative to other EZ economies in Cyprus and Greece consistent with significant downward income adjustment for these relative to other EZ economies, as can be seen via a comparison of the first and second column of Table 2. A relative fall in the price of non-tradeables was also observed in Austria, Germany, France, Iceland and the U.K., associated with a relative fall in income during the period for the last three countries. Moreover, as shown in Table 2, mean and median tradeable goods prices visibly fell in Cyprus, Iceland, Ireland, Italy and the UK.

Columns 1-4 of Table 2 show that for the majority of countries, income deviations and LOP deviations change over time in the same direction, consistent with the Balassa-Samuelson hypothesis. However, for some economies like Portugal and Greece a severe fall in relative income is accompanied by little adjustment in prices. As we adjust prices for VAT rates, this is not driven by rising taxes in these countries during the Crisis. Instead, this is likely related to market structure (lack of competition) and the prevalence of price rigidities in these economies. Interestingly, Germany becomes relatively cheaper than the EZ average between 2005 and 2014, which could reflect a persistent productivity or other cost advantages. For instance, wage deviations in Germany fall 
from 0.688 to $0.502^{5}$ between 2004 and 2014 suggesting that Germany becomes more competitive in labor cost, which in turn can cause a fall in prices of both tradeables and non-tradeables.

Comparing the distribution of LOP deviations before and after the Crisis

In Figures 1 and 2, we plot LOP deviations for the 31-country sample and for the $19 \mathrm{EZ}$ countries, respectively. Each line represents an estimate of the density of LOP deviations (common currency prices compared to the cross-country mean), good-by-good, for 2005 and 2014. We distinguish between traded and non-traded goods and plot their separate distributions for 2014 and 2005 for the 31-country sample and for the $19 \mathrm{EZ}$ economies. These figures show that price dispersion is lower for tradeables as compared to non-tradeables, and that dispersion for both tradeables and non-tradeables becomes lower during the Crisis.

In addition to the visual evidence, we consider the Kolmogorov-Smirnov test for the null of equality of the empirical distribution functions and report results in Table 3 . The Kolmogorov-Smirnov tests suggest that the empirical distribution of LOP deviations in 2005 is different than in 2014 for both groups of countries. Kurtosis of the LOP deviations distribution for the complete sample of goods falls slightly from 5.1 to 4.9 for the 19 EZ economies as a whole between 2005 and 2014, reflecting the drop in kurtosis for the tradeable goods distribution from 5.347 to 5.224 . Kurtosis is a measure of peakedness but also tailedness of the distribution. In the case of the distributions for 2005, higher kurtosis values are associated with fatter tails rather than higher peakednes $\AA^{6}$ in 2005 as compared to 2014 , so we cannot infer that the degree of integration was lower in 2014 as compared to 2005

\footnotetext{
${ }^{5}$ We do not present these wage deviations in a Table here to save space but this is available upon request

${ }^{6}$ As pointed by Ruppert (1987) kurtosis is a measure of both peakedness and tail weight, with higher kurtosis values indicating peakedness and fatter tails of the distribution, while lower kurtosis values indicate flatness and thinner tails. Kurtosis can be poorly informative about the change of the degree of integration over time to the extent that the comparison might involve distributions with very different tail characteristics, so it would not be clear whether high kurtosis values are associated with peakedness or fat tails for both distributions, or with peakedness for one distribution and fat tails for another distribution.
} 
based on the kurtosis values reported in Table 3 . In fact, the higher peakedness of the distributions for 2014 as compared to 2005 for both tradeables and non-tradeables is evident in Figures 1 and 27

Next, we present the density functions for each of the 19 EZ economies and the UK in Figures 3 and 4. These graphs show an estimate of the density of good-by-good deviations from the LOP, $q_{i j t}$, calculated as in equation (1), for 2005 and 2014 respectively the latest and earliest available dates before and after the incidence of the Crisis. Following that, in Table 4, we report the KolmogorovSmirnov test for the null of equality of these distribution functions for each country in 2014 and 2005 for the whole sample of goods, for traded, and for non-traded goods. In the last six columns of Table 4, we present kurtosis values for the LOP deviations distributions for each country for all goods, tradeables, and non-tradeables in 2005 and 2014.

In Figure 3, we present the density functions for each of the $19 \mathrm{EZ}$ economies and the UK for traded goods. As we can see there, the density functions for the seven new EZ economies (Cyprus, Estonia, Latvia, Lithuania, Malta, the Slovak Republic and Slovenia) are more highly peaked around zero for 2014 as compared to 2005. Moreover, with the exception of Cyprus, there is a visible shift of the density function to the right for these EZ economies, suggesting tradeable goods became relatively more expensive there during the period consistent with the evidence in Table 2 for mean and median LOP deviations. As shown in Table 4, for all of these countries we reject the null that the distribution functions in 2014 and 2005 were identical. By contrast, for the original EZ countries, such as Finland, Greece, Luxembourg, the Netherlands, and Spain, we cannot reject the null that the distribution functions in 2014 and 2005 are identical. Furthermore, in Table 4 we can see that kurtosis fell for tradeables in Austria, France, Greece, Italy, Latvia, Luxembourg and

\footnotetext{
${ }^{7}$ We note that when we eliminate outliers by restricting the tails of the distributions with the support ranging from -1.5 to 1.5 so that fat tails are no longer an issue, kurtosis values for the EZ 19 increase, for example, from 4.762 in 2005 to 4.895 in 2014 for tradeables (not shown in Table 3 nor reflected in Figure 2 .
} 
Malta. However, since the density functions for these countries are all visibly more highly peaked in 2014 as compared to 2005 in Figure 3, higher kurtosis values for 2005 in Table 4 merely indicate fatter tails in 2005 as compared to 2014 for these countries rather than a lower degree of market integration for tradeable goods.

In Figure 4, we present the density functions for each of the $19 \mathrm{EZ}$ economies and the UK for nontraded goods. Figure 4 shows that for some countries like Austria, Finland, France, Germany, and Portugal, the density functions are visibly less highly peaked at zero for 2014 as compared to 2005, suggesting a lower degree of integration for non-traded goods after the incidence of the Crisis 8 As can be seen in Table 2, non-traded goods in Austria, France, Germany, and Portugal became overall relatively cheaper during this period, whereas in Finland they were little changed. For new EZ countries, density functions are more highly peaked at zero for 2014 as compared to 2005 in all cases except for Slovenia, suggesting a higher degree of integration for non-traded goods. As shown in Table 4, kurtosis fell for Cyprus, Ireland, Portugal and Slovenia. For Cyprus and Ireland this fall in kurtosis is associated with falling prices for non-tradeables relative to the EZ19 during this period, while in the case of Slovenia the fall in kurtosis is associated with non-tradeables prices rising relative to the EZ19. As we can see in Table 2, non-tradeables are becoming more expensive over this period in the majority of new EZ countries.

Finally, for the purposes of Table 5, we trace the exact position of each individual good in the distribution of LOP deviations in order to examine whether goods tend to remain systematically cheaper or more expensive in specific countries during the recent Crisis. Persistence of LOP deviations is defined here as the percentage of goods which were on the same side of the distribution (either above or below zero) for the pair of years being compared in each case. We trace the position of

\footnotetext{
${ }^{8}$ That kurtosis values are greater in 2014 as compared to 2005 for the first four countries, is in this case due to fatter tails in 2014 as compared to 2005.
} 
these LOP deviations for individual tradeable goods over time to infer whether the revealed price advantage of a country tends to persist over time. We focus on internationally traded goods and even remove the effect of income in some cases in order to focus on the traded component.9 The notion of price advantage we consider here will thus be plausibly closely related to trade.

Table 5 presents this measure of persistence and correlations between the LOP deviations of internationally traded goods in different periods for 31 European countries. These correlations are calculated by pooling the LOP deviations in an ordered vector according to the matched goods identifier for every country for one period, then doing the same for the exact same goods and countries ordered in the same manner for a second period, and computing the correlation between any two such ordered vectors (periods).

The first thing we can observe from Table 5 is that the computed correlations across pairs of years are high (e.g. as high as 68\% for Turkey for the 10-year gap between 2005 and 2014) and exhibit variation across EZ countries (from $32 \%$ in Malta to $62 \%$ in Lithuania for the same gap). Moreover, the correlations between 2010 and 2014 are greater on average and for each and every country separately as compared to the correlations between 2005 and 2010, with respective average correlations of $71 \%$ versus $57 \%$ for the first and second pair of years being compared.

Regarding our measure of persistence, we observe that the percentage of individual goods that were more expensive in a specific country for both 2014 and 2010, is comparable to the percentage of goods that were more expensive for both 2010 and 2005. For those countries where there was a visible change, this percentage typically went up e.g. from $43 \%$ to $50 \%$ in Belgium. As a result, the average persistence as captured by this percentage across all countries was $33 \%$ between 2005

\footnotetext{
${ }^{9}$ Income is plausibly closely associated with the non-traded component in a basic retail price model as in Crucini, Telmer and Zachariadis (2005) where each good is produced by a traded input combined with a non-traded one. In our current application, we focus on the traded component so that our results are not driven by the documented close link between income and prices.
} 
and 2010, and $35 \%$ between 2010 and 2014. Strikingly, the cross-country average of the percentage of individual goods that were more expensive in both 2005 and 2014 was again $33 \%$.

Finally, we calculate persistence of LOP deviations for non-tradeables. This is useful as if persistence values turn out to be higher for non-tradeables it would provide justification for the use of percentages as a proxy for persistence ${ }^{10}$ Indeed, price advantage appears overall to be more persistent for non-tradeables than for tradeables in relatively poorer countries, and price disadvantage more persistent for non-tradeables than for tradeables in relatively rich countries 11

Overall, our findings here suggest that rigidities that rendered certain goods more expensive for 2010 and 2005 in certain locations, were also largely in place in 2014 for those same locations. This is a particularly striking finding in the case of countries that faced problems and subsequently went through formal or informal adjustment programs, such us in Cyprus, Greece, Ireland, Italy, Portugal and Spain.

\section{Conclusion}

We have shown that the process of European integration as captured by the proximity of prices across EZ and European economies at large, continued during the Eurozone Crisis. Moreover, we have shown that individual economies adjusted via different channels during this period. For example, Greece's adjustment occurred primarily via a relative fall in the price of non-tradeables but not tradeables relative to the rest of the EZ, whereas Ireland and Italy adjusted mostly via

\footnotetext{
${ }^{10}$ We thank an anonymous referee of this journal for pointing this out. Results from this exercise are available upon request.

${ }^{11}$ More specifically, our results show that for the vast majority of rich countries in our sample (such as Austria, Belgium, Denmark, France, Germany, Ireland, Luxembourg, the Netherlands, Sweden, Switzerland, and the UK) the percentage of non-traded goods that were more expensive for any pair of years is higher than the respective share of traded goods. Moreover, for relatively poorer countries in our sample (such as Bulgaria, Cyprus, Czech Republic, Estonia, Hungary, Latvia, Lithuania, Malta, Poland, Romania, Slovakia, Slovenia, and Turkey) the percentage of non-traded goods that were cheaper for any pair of years is higher than the respective share of traded goods.
} 
a fall in the relative price of tradeables. However, a large percentage of individual internationally traded goods that were relatively more expensive in a country in 2010 and 2005 remained so in 2014, suggesting that persistent rigidities rendering certain goods more expensive in specific locations persisted during the Crisis. This latter result has important implications as to the direction policy should follow in the Eurozone. While well-deserved policy emphasis has been placed by the Eurozone on correcting fiscal imbalances and more recently on monetary policy to address the resulting deflationary bias, our work suggests that little has been done in practice to break structural rigidities in goods and services markets during the period under study. 


\section{Compliance with Ethical Standards}

Funding: No funding was received for this study.

Conflict of Interest: The authors declare that they have no conflict of interest.

Ethical Approval: This article does not contain any studies with human participants or animals performed by any of the authors. 


\section{References}

[1] Allington, Nigel F.B., Paul A. Kattuman, and Florian A. Waldmann (2005) "One Market, One Money, One Price? Price Dispersion in the European Union," International Journal of Central Banking 1(3), 73-115.

[2] Brock, W., and C. Hommes (1997) "A Rational Route to Randomness," Econometrica 65,10591095.

[3] Crucini, Mario, Chris Telmer, and Marios Zachariadis, (2005) "Understanding European Real Exchange Rates," The American Economic Review 95(3), 724-738.

[4] Dixit, A. (1989) "Hysteresis, Import Penetration and Exchange Rate Pass-Through, " Quarterly Journal of Economics 104, 205-28.

[5] Faber, R.P. and Stockman A.C.J. (2009) "A Short History of Price Level Convergence in Europe, "Journal of Money Credit and Banking 41 (2-3), 461-477.

[6] Fischer, Christoph (2012) "Price Convergence in the EMU? Evidence from Micro Data," European Economic Review 56(4), 757-776.

[7] Glushenkova, Marina and Marios Zachariadis (2016), "Understanding post-Euro Law-of-OnePrice Deviations," Journal of Money, Credit and Banking 48(6), 1073-1111.

[8] Guerreiro, David and Valérie Mignon (2013) "On Price Convergence in Eurozone," Economic Modelling 34(C), 42-51.

[9] Imbs, Jean, Haroon Mumtaz, Morten O. Ravn and Hélène Rey (2010) “One TV, One Price?" Scandinavian Journal of Economics 112(4), 753-781.

[10] Inanc, Ozlem and Marios Zachariadis (2012) "The Importance of Trade Costs in Deviations from the Law of One Price: estimates based on the Direction of Trade," Economic Inquiry $50(3), 667-689$.

[11] Krugman, P. R. (1989) "Exchange Rate Instability," (MIT: Cambridge).

[12] Lee Inkoo (2010) "Geographic Price Dispersion in Retail Markets: Evidence from Micro-Data," Journal of Macroeconomics 32(4), 1169-1177.

[13] Lee, Inkoo and J. Shin (2010) "Real Exchange Rate Dynamics in the Presence of Nontraded Goods and Transaction Costs," Economics Letters 106(3), 216-218.

[14] O'Connell, P.G.J., and S.-J. Wei (2002) "The Bigger They Are, the Harder They Fall: Retail Price Differences across US Cities, "Journal of International Economics 56, 21-53.

[15] Parsley David, and S. J. Wei (2007) "A Prism into the PPP Puzzles: The Micro-Foundations of Big Mac Real Exchange Rates," The Economic Journal 117(523), 1336-1356.

[16] Parsley David and S. J. Wei (2008) "In Search of a Euro Effect: Big Lessons from a Big Mac Meal?" Journal of International Money and Finance 27, 260-276.

[17] Ruppert, D. (1987) "What is Kurtosis? An Influence Function Approach, " The American Statistician 41, 1-5. 
Table 1: Exemplary set of goods matched between 2005 and 2014

Description 2005

Cornflakes, KELLOGG'S, (Excl.: frosted, choco or oth.spec.Cornflakes), 250-500g

Yoghurt drink, ACTIMEL (DANONE), multipack 4-6, 100-125g/ml per piece

Cheese, processed, KRAFT PHILADELPHIA, CLASSIC, Fat content: approx.70 \%, 150-300g

Tinned White Beans, HEINZ, in tomato sauce, net weight $350-450 \mathrm{~g}$

Coffee, instant, NESCAFE GOLD, $100 \mathrm{~g}$

Tea, Earl Grey, TWININGS, approx. 25 enveloped bags

Mint chocolate, AFTER EIGHT (NESTLE), plain dark chocolate with mint filling, $200-400 \mathrm{~g}$

Jellies, wine gum, HARIBO, any flavour, 100-230g

Tomato-ketchup, HEINZ, $300-600 \mathrm{~g}$

Mineral water, natural, EVIAN, 1 - 2

Energy drink, Red Bull, can - $250 \mathrm{ml}$

Carbonated drink, Coca Cola, $0.33-0.51$

Spirit, Whisky - Scotch, JOHNNIE WALKER, Red label, 0.7 - 11

Spirit, Liqueur, BAILEYS ORIGINAL IRISH CREAM, $0.7-11$

Aperitif, Bitter Campari, BITTER CAMPARI, Package: bottle, 0.7-11

Cigarettes, with filter, CAMEL, (Excl.: light)

Men's blue jeans - Levi's 501

Parquet, oak layer, TARKETT

Baby's high chair, STOKKE

Double bed, IKEA

Wardrobe, IKEA

Sofa, IKEA, KLIPPAN

Bookcase, artificial surface, IKEA

Mirror, IKEA

Bathroom cabinet, IKEA

Refrigerator, WHIRLPOOL, ARC 1820

Vacuum cleaner, PHILIPS, FC 9126/20 Specialist for carpets

Glass, wine, LUMINARC (consolidated under Arcoroc), any available e.g. Domino

Frying pan, TEFAL / T-FAL (trademark of SEB group), Ambiance - Essence - Activ

Battery, DURACELL, Ultra M3 Alkaline MN 1500 - AA Mignon 1.5

Motor cars, Diesel engine OPEL (VAUXHALL) Astra 1.7 CDTI Ecotec (100cv)

Motor cars, Petrol engine, $<1,200 \mathrm{cc}$ NISSAN Micra 1.0

Motor cars, Petrol engine, 1,700 - 2,999cc AUDI A4 2.0 FSI

Motor cars, Petrol engine, $>3,000 \mathrm{cc}$ BMW 7 series 735 i

Car battery VARTA Blue dynamic

Compact digital camera, CANON, IXUS II

Tennis racket HEAD Radical Junior

Doll, ZAPF, Baby Born

Magazine, monthly, COSMOPOLITAN,

Men's wrist-watch; CITIZEN

Baby car seat; MAXI COSI

Acetylsalicylic acid, ATC: B01AC06, Strength: $100 \mathrm{mg}, 20$ - 30 tablets / original

Flight, International - Berlin, return ticket

Services, Cobbler - men's classic shoes

Plumber, hourly charge

Technician, oil burner of heating system, total service

Water supply, excluding sewerage - $100 \mathrm{~m} 3$

\section{Description 2014}

Cornflakes, KELLOGG'S

Yoghurt drink, multipack, DANONE Actimel

Cream cheese, KRAFT Philadelphia Classic

Tinned white beans in tomato sauce, HEINZ

Instant coffee, NESCAFE Gold

Earl grey tea, TWININGS

Mint chocolate, After Eight, NESTLE

Jellies, HARIBO

Tomato ketchup, HEINZ

Mineral water, EVIAN

Energy drink, RED BULL

COCA COLA, can

Scotch whisky, JOHNNIE WALKER, Red label

Liqueur, BAILEYS, Original Irish cream

Aperitif, BITTER CAMPARI

Cigarettes, with filter, CAMEL

Men's blue jeans, LEVI'S

Parquet, oak layer, TARKETT

Baby's high chair, STOKKE

Double bed frame, IKEA, Malm

Wardrobe, IKEA, Brimness

Sofa, 2-seater, IKEA, Klippan

Bookcase, artificial surface, IKEA, Billy

Mirror, IKEA, Grundtal

Bathroom cabinet, IKEA, Hemnes

Refrigerator, with freezer, WHIRLPOOL ARC104

Vacuum cleaner (dust bag) PHILIPS FC9170/FC9173/FC9176

Glass, wine, LUMINARC/ARCOROC

Frying pan, TEFAL Reference or Talent

Battery, DURACELL

Motor car, diesel, OPEL / VAUXHALL Astra

Motor car, petrol, $<1,200 \mathrm{cc}$, NISSAN Micra

Motor car, petrol, $1,700-2,999 \mathrm{cc}$, AUDI A4

Motor car, petrol, $>3,000 \mathrm{cc}$, BMW 7 series

Car battery, VARTA Blue dynamic, $60 \mathrm{Ah}$

Digital compact camera, CANON Digital Ixus 255 HS

Tennis racket, HEAD Radical Junior

Doll, ZAPF Baby Born

Magazine, monthly, Cosmopolitan

Wrist-watch, CITIZEN

Baby car seat, MAXI COSI

Acetylsalicylic acid, original, 100mg

Flight, International - Berlin, return ticket

Shoe repair, men's classic shoes

Plumber, hourly charge

Technician, oil burner of heating system, total service

Water supply, $100 \mathrm{~m} 3$, excluding sewerage 
Table 2: Mean and median LOP deviations

Income deviations $\quad$ Average LOP deviations

$$
\text { non-traded goods traded goods }
$$

\section{country}

Austria

Belgium

Bulgaria

Cyprus

Czech Republic

Denmark

Estonia

Finland

France

Germany

Greece

Hungary

Iceland

Ireland

$$
\text { Italy }
$$

Latvia

Lithuania

Luxembourg

Malta

Netherlands

Norway

Poland

Portugal

Romania

Slovak Republic

Slovenia

Spain

Sweden

Switzerland

Turkey

United Kingdom
2005

0.458

0.420

$-1.836$

0.041

$-0.599$

0.698

$-0.855$

0.472

0.358

0.356

$-0.075$

$-0.773$

0.841

0.739

0.274

$-1.169$

$-1.129$

1.195

$-0.428$

0.537

1.011

$-1.108$

$-0.257$

$-1.647$

$-0.734$

$-0.291$

0.087

0.574

0.816

$-1.190$

0.541

\section{4}

0.448

0.360

$-1.437$

$-0.187$

$-0.515$

0.637

$-0.504$

0.413

0.264

0.374

$-0.418$

$-0.845$

0.470

0.517

0.069

$-0.743$

$-0.692$

1.283

$-0.245$

0.457

1.080

$-0.834$

$-0.403$

$-1.193$

$-0.573$

$-0.311$

$-0.109$

0.583

0.964

$-1.003$

0.348

2014

0.105

2005

0.176

0.046

0.109

$-0.836$

$-0.144$

$-0.612$

0.374

$-0.256$

0.338

0.107

0.042

$-0.177$

$-0.589$

0.256

0.234

0.082

$-0.354$

$-0.507$

0.197

$-0.284$

0.144

0.599

$-0.505$

$-0.163$

$-0.714$

$-0.398$

$-0.165$

$-0.065$

0.387

0.505

$-0.480$

0.187

$-0.261$

$-0.310$

$-0.336$

$-0.051$

0.014

0.280

$-0.376$

$-0.031$

$-0.502$

$-0.104$

$-0.05$

$-0.408$

0.241
0.007

0.031

$-0.496$

0.077

$-0.256$

0.165

0.121

0.020

0.024

$-0.063$

$-0.306$

0.356

0.170

0.074

0.074

$-0.319$

0.11

0.29

2014

0.040

0.058

$-0.382$

0.013

$-0.230$

0.177

$-0.132$

0.102

0.024

$-0.012$

$-0.066$

$-0.331$

0.204

0.109

0.030

$-0.147$

$-0.209$

0.083

0.031

0.013

0.347

$-0.350$

$-0.065$

-0.323
-0.181

$-0.091$

$-0.086$

0.160

0.301

$-0.219-0.218$

$\begin{array}{ll}0.061 & -0.013\end{array}$
Median LOP deviations

non-traded goods traded goods

2005

0.173

0.053

$-1.064$

0.034

$-0.823$

0.427

$-0.560$

0.317

0.194

0.135

$-0.051$

$-0.509$

0.592

0.269

0.066

$-0.610$

$-0.662$

0.234

$-0.349$

0.189

0.546

$-0.465$

$-0.129$

$-1.098$

$-0.762$

$-0.291$

$-0.022$

0.312

0.468

$-0.373$

0.231
2014
0.107
0.090

$2005 \quad 2014$

$\begin{array}{ll}0.002 & 0.025\end{array}$

$\begin{array}{lll}-0.868 & -0.402 & -0.317\end{array}$

$\begin{array}{lll}-0.110 & 0.094 & 0.021\end{array}$

$\begin{array}{lll}-0.597 & -0.206 & -0.207\end{array}$

$\begin{array}{lll}0.415 & 0.146 & 0.176\end{array}$

$\begin{array}{lll}-0.258 & -0.215 & -0.102\end{array}$

$\begin{array}{lll}0.316 & 0.099 & 0.101\end{array}$

$\begin{array}{lll}0.090 & -0.009 & 0.017\end{array}$

$\begin{array}{lll}0.008 & 0.015 & -0.006\end{array}$

$\begin{array}{lll}-0.205 & -0.042 & -0.055\end{array}$

$\begin{array}{lll}-0.617 & -0.259 & -0.277\end{array}$

$\begin{array}{lll}0.297 & 0.329 & 0.197\end{array}$

$\begin{array}{lll}0.240 & 0.152 & 0.098\end{array}$

$\begin{array}{lll}0.095 & 0.056 & 0.019\end{array}$

$\begin{array}{lll}-0.323 & -0.245 & -0.108\end{array}$

$\begin{array}{lll}-0.520 & -0.264 & -0.149\end{array}$

$\begin{array}{lll}0.235 & 0.068 & 0.055\end{array}$

$\begin{array}{lll}-0.276 & -0.021 & 0.031\end{array}$

$\begin{array}{lll}0.165 & 0.022 & 0.009\end{array}$

$\begin{array}{lll}0.618 & 0.253 & 0.346\end{array}$

$\begin{array}{lll}-0.482 & -0.350 & -0.311\end{array}$

$\begin{array}{lll}-0.200 & -0.037 & -0.040\end{array}$

$\begin{array}{lll}-0.699 & -0.414 & -0.263\end{array}$

$\begin{array}{lll}-0.397 & -0.239 & -0.142\end{array}$

$\begin{array}{lll}-0.169 & -0.100 & -0.080\end{array}$

$\begin{array}{lll}-0.055 & -0.041 & -0.060\end{array}$

$\begin{array}{lll}0.423 & 0.121 & 0.151\end{array}$

$\begin{array}{lll}0.514 & 0.258 & 0.299\end{array}$

$\begin{array}{lll}-0.509 & -0.194 & -0.213\end{array}$

$\begin{array}{lll}0.150 & 0.042 & -0.014\end{array}$ 
Table 3: LOP deviations distribution characteristics and tests for the equality of distributions.

\begin{tabular}{ccllll} 
& Kolmogorov-Smirnov test & \multicolumn{2}{c}{ Mean dispersion } & \multicolumn{2}{c}{ Kurtosis values } \\
year & 2014 vs2005 & 2014 & 2005 & 2014 & 2005 \\
EZ19 & 0.000 & 0.279 & 0.327 & 4.945 & 5.130 \\
ALL & 0.000 & 0.357 & 0.401 & 4.647 & 4.674 \\
EZ19_TR & 0.000 & 0.254 & 0.295 & 5.224 & 5.347 \\
EZ19_NTR & 0.000 & 0.384 & 0.459 & 3.574 & 3.617 \\
ALL_TR & 0.000 & 0.322 & 0.361 & 4.915 & 4.954 \\
ALL_NTR & 0.000 & 0.504 & 0.569 & 3.253 & 3.234
\end{tabular}

Notes: For the Kolmogorov-Smirnov test we consider comparisons of LOP deviations distributions between different years. The LOP deviations are constructed using overall 31-country sample, or $19 \mathrm{EZ}$ countries, as indicated in the first column of each row. In the first column, we report P-values for the Kolmogorov-Smirnov test of the null of equality of distribution functions in 2014 and 2005. In the next two columns, we report the mean (over goods) cross-country price dispersion in 2014 and 2005. In the last two columns, we report kurtosis values for the LOP deviations distributions for each year. EZ19 - We report results using LOP deviations for the nineteen EZ countries (Austria, Belgium, Cyprus, Estonia, Finland, France, Germany, Greece, Ireland, Italy, Latvia, Lithuania, Luxembourg, Malta, the Netherlands, Portugal, Slovak Republic, Slovenia, and Spain) ALL - We report results for the thirty one countries (Austria, Belgium, Bulgaria, Cyprus, Czech Republic, Denmark, Estonia, Finland, France, Germany, Greece, Hungary, Iceland, Ireland, Italy, Latvia, Lithuania, Luxembourg, Malta, the Netherlands, Norway, Poland, Portugal, Romania, Slovak Republic, Slovenia, Spain, Sweden, Switzerland, Turkey, and the UK) 
Table 4: LOP deviations distribution characteristics and tests for the equality of distributions for each country.

\begin{tabular}{|c|c|c|c|c|c|c|c|c|c|}
\hline \multirow[b]{2}{*}{ country } & \multicolumn{3}{|c|}{$\begin{array}{l}\text { Kolmogorov-Smirnov test } \\
2014 \text { vs } 2005\end{array}$} & \multicolumn{6}{|c|}{ Kurtosis values } \\
\hline & all & traded & non-traded & 2014 & 2005 & 2014 & 2005 & 2014 & 2005 \\
\hline Austria & 0.250 & 0.008 & 0.002 & 4.160 & 4.050 & 3.503 & 4.449 & 4.569 & 3.478 \\
\hline Belgium & 0.000 & 0.000 & 078 & 5.667 & 5.122 & 5.68 & 5.283 & 5.721 & 4.492 \\
\hline Bulgaria & 0.000 & 0.000 & 0.000 & 3.130 & 2.549 & 3.664 & 2.853 & 3.289 & 2.714 \\
\hline Cyprus & 0.000 & 0.000 & 0.001 & 5.031 & 5.223 & 4.763 & 4.406 & 4.316 & 4.557 \\
\hline Czech Republic & 0.000 & 0.001 & 0.000 & 4.400 & 3.523 & 4.804 & 3.940 & 3.691 & 2.837 \\
\hline Denmark & 0.477 & 0.097 & 0.322 & 5.014 & 3.948 & 5.954 & 4.507 & 3.583 & 3.738 \\
\hline Estonia & 0.000 & 0.000 & 0.000 & 4.357 & 3.429 & 4.090 & 4.154 & 4.253 & 2.587 \\
\hline Finland & 0.143 & 0.278 & 608 & 5.551 & 4.138 & 6.666 & 4.715 & 4.432 & 3.899 \\
\hline France & 0.183 & 0.041 & 0.002 & 4.405 & 3.719 & 3.970 & 4.335 & 3.996 & 3.365 \\
\hline Germany & 0.000 & 0.002 & 008 & 5.033 & 3.885 & 4.573 & 3.818 & 4.389 & 3.488 \\
\hline Greece & 0.076 & 0.802 & 0.000 & 5.056 & 4.581 & 4.252 & 4.830 & 4.887 & 3.409 \\
\hline Hungary & 0.006 & 0.001 & 0.027 & 3.813 & 3.774 & 4.929 & 4.220 & 2.989 & 3.720 \\
\hline Iceland & 0.000 & 0.000 & 0.000 & 5.197 & 4.079 & 4.858 & 3.668 & 5.528 & 5.190 \\
\hline Ireland & 0.000 & 0.000 & 342 & 3.869 & 3.754 & 4.023 & 3.342 & 3.703 & 4.668 \\
\hline Italy & 0.017 & 0.001 & 800 & 4.507 & 4.023 & 4.098 & 4.265 & 3.994 & 3.140 \\
\hline Latvia & 0.000 & 0.000 & 000 & 3.594 & 3.799 & 3.706 & 4.263 & 4.647 & 3.786 \\
\hline Lithuania & 0.000 & 0.000 & 000 & 3.736 & 3.297 & 3.935 & 3.165 & 5.512 & 3.455 \\
\hline Luxembourg & 0.607 & 0.440 & $\mathrm{c}$ & 4.457 & 4.333 & 4.513 & 4.743 & 4.732 & 3.904 \\
\hline Malta & 0.001 & 0.001 & $\mathrm{c}$ & 4.409 & 4.097 & 3.822 & 3.990 & 3.631 & 3.350 \\
\hline Netherlands & 0.994 & 0.741 & 191 & 4.825 & 4.299 & 4.543 & 4.424 & 6.353 & 3.660 \\
\hline Norway & 0.000 & 0.000 & 087 & 3.244 & 3.234 & 3.341 & 3.762 & 3.868 & 3.160 \\
\hline Poland & 0.503 & 0.250 & 620 & 3.704 & 3.901 & 3.652 & 3.622 & 3.751 & 4.528 \\
\hline Portugal & 0.077 & 0.025 & 0.026 & 3.818 & 4.298 & 3.947 & 3.855 & 3.505 & 4.781 \\
\hline Romania & 0.000 & 0.000 & 0.000 & 3.256 & 2.767 & 3.510 & 2.928 & 2.987 & 3.134 \\
\hline Slovak Republic & 0.000 & 0.000 & 0.000 & 4.531 & 2.995 & 5.425 & 3.386 & 4.223 & 3.785 \\
\hline Slovenia & 0.000 & 0.003 & 0.001 & 4.116 & 3.947 & 4.516 & 3.453 & 2.869 & 2.915 \\
\hline Spain & 0.058 & 165 & 0.326 & 7.086 & 4.581 & 7.748 & 4.890 & 4.316 & 3.453 \\
\hline Sweden & 0.004 & 009 & 0.015 & 6.567 & 5.405 & 8.196 & 5.993 & 5.156 & 4.888 \\
\hline Switzerland & 0.014 & .041 & 0.378 & 3.735 & 3.673 & 4.059 & 3.726 & 3.852 & 5.721 \\
\hline Turkey & 0.446 & 696 & 0.205 & 3.503 & 3.536 & 3.462 & 3.489 & 3.186 & 3.116 \\
\hline ngaom & 0.000 & 0.000 & 0.009 & 7.320 & 4.984 & 7.370 & 4.249 & 5.496 & 3.847 \\
\hline
\end{tabular}

Notes: For the Kolmogorov-Smirnov test we consider comparisons of LOP deviations distributions between different years for each country. In the first three columns, we report P-values for the Kolmogorov-Smirnov test of the null of equality of distribution functions in 2014 and 2005 for the whole sample of goods, traded and non-traded goods, respectively. In the next six columns, we report kurtosis values for the LOP deviations distributions for each year for each sample of goods. 
Table 5: Persistence of LOP Deviations by Country and Time Gap.

\begin{tabular}{|c|c|c|c|c|c|c|c|c|c|c|c|c|c|c|c|}
\hline \multirow{3}{*}{ country } & \multicolumn{5}{|c|}{ 2014-2005 gap } & \multicolumn{5}{|c|}{ 2014-2010 gap } & \multicolumn{5}{|c|}{ 2010-2005 gap } \\
\hline & \multirow[t]{2}{*}{ correl. } & \multicolumn{2}{|c|}{ persistence } & \multicolumn{2}{|c|}{ persistence* } & \multirow[t]{2}{*}{ correl. } & \multicolumn{2}{|c|}{ persistence } & \multicolumn{2}{|c|}{ persistence* } & \multirow[t]{2}{*}{ correl. } & \multicolumn{2}{|c|}{ persistence } & \multicolumn{2}{|c|}{ persistence* } \\
\hline & & above & below & above & below & & above & below & above & below & & above & below & above & below \\
\hline Austria & 0.488 & 0.346 & 0.290 & 0.136 & 0.608 & 0.671 & 0.421 & 0.323 & 0.218 & 0.623 & 0.541 & 0.343 & $0.320 !$ & 0.125 & 0.624 \\
\hline Belgium & 0.412 & 0.409 & 0.211 & 0.165 & 0.534 & 0.673 & 0.500 & 0.221 & 0.257 & 0.492 & 0.477 & 0.431 & 0.234 & 0.209 & 0.515 \\
\hline Bulgaria & 0.599 & 0.055 & 0.788 & 0.413 & 0.342 & 0.762 & 0.065 & 0.815 & 0.387 & 0.418 ! & 0.672 & 0.054 & 0.760 & 0.386 & 0.391 ! \\
\hline Cyprus & 0.514 & 0.417 & 0.245 & 0.394 & 0.268 & 0.802 & 0.437 & 0.341 & 0.425 & 0.364 & 0.544 & 0.474 & 0.217 & 0.422 & 0.278 \\
\hline Czech Republic & 0.592 & 0.110 & 0.595 & 0.236 & 0.449 & 0.695 & 0.121 & 0.657 & 0.232 & 0.533 & 0.652 & 0.141 & 0.614 & 0.250 & 0.484 \\
\hline Denmark & 0.487 & 0.619 & 0.114 & 0.316 & $0.339 !$ & 0.716 & 0.635 & 0.169 & 0.351 & 0.410 & 0.526 & 0.594 & 0.129 & 0.269 & 0.401 \\
\hline Estonia & 0.572 & 0.140 & 0.595 & 0.371 & $0.352 !$ & 0.764 & 0.211 & 0.561 & 0.411 & $0.376 !$ & 0.712 & 0.149 & 0.625 & 0.362 & 0.403 ! \\
\hline Finland & 0.592 & 0.568 & 0.154 & 0.306 & 0.400 & 0.759 & 0.598 & 0.216 & 0.362 & 0.454 & 0.691 & 0.574 & 0.173 & 0.298 & 0.441 \\
\hline France & 0.514 & 0.366 & 0.307 & 0.205 & 0.528 & 0.601 & 0.425 & 0.323 & 0.271 & 0.492 & 0.529 & 0.382 & 0.324 & 0.220 & 0.521 \\
\hline Germany & 0.487 & 0.339 & $0.324 !$ & 0.149 & 0.581 & 0.681 & 0.344 & 0.399 & 0.182 & 0.602 & 0.479 & 0.348 & $0.333 !$ & 0.184 & 0.550 \\
\hline Greece & 0.466 & 0.223 & 0.437 & 0.255 & 0.378 & 0.688 & 0.302 & 0.413 & 0.372 & $0.339 !$ & 0.597 & 0.278 & 0.409 & 0.259 & 0.419 \\
\hline Hungary & 0.497 & 0.046 & 0.758 & 0.187 & 0.460 & 0.755 & 0.063 & 0.833 & 0.251 & 0.537 & 0.518 & 0.054 & 0.731 & 0.210 & 0.474 \\
\hline Iceland & 0.507 & 0.739 & 0.037 & 0.509 & 0.154 & 0.693 & 0.588 & 0.169 & 0.412 & 0.290 & 0.451 & 0.623 & 0.053 & 0.412 & 0.201 \\
\hline Ireland & 0.552 & 0.555 & 0.145 & 0.295 & 0.436 & 0.698 & 0.508 & 0.225 & 0.323 & 0.450 & 0.554 & 0.571 & 0.147 & 0.317 & 0.384 \\
\hline Italy & 0.478 & 0.369 & 0.264 & 0.255 & 0.442 & 0.684 & 0.427 & 0.303 & 0.320 & 0.422 & 0.490 & 0.398 & 0.226 & 0.252 & 0.426 \\
\hline Latvia & 0.605 & 0.109 & 0.556 & 0.457 & 0.303 & 0.761 & 0.247 & 0.546 & 0.500 & 0.306 & 0.708 & 0.145 & 0.615 & 0.456 & 0.347 \\
\hline Lithuania & 0.616 & 0.121 & 0.601 & 0.415 & 0.352 & 0.803 & 0.182 & 0.635 & 0.411 & $0.401 !$ & 0.650 & 0.144 & 0.626 & 0.390 & 0.412 ! \\
\hline Luxembourg & 0.437 & 0.473 & 0.212 & 0.046 & 0.768 & 0.600 & 0.551 & 0.186 & 0.077 & 0.788 & 0.488 & 0.525 & 0.186 & 0.065 & 0.783 \\
\hline Malta & 0.318 & 0.278 & 0.336 & 0.416 & 0.239 & 0.672 & 0.353 & $0.379 !$ & 0.478 & 0.283 & 0.476 & 0.244 & 0.438 & 0.391 & 0.310 \\
\hline Netherlands & 0.497 & 0.364 & $0.348 !$ & 0.140 & 0.652 & 0.759 & 0.364 & $0.393 !$ & 0.163 & 0.664 & 0.512 & 0.376 & $0.343 !$ & 0.136 & 0.662 \\
\hline Norway & 0.632 & 0.850 & 0.031 & 0.445 & 0.270 & 0.709 & 0.779 & 0.052 & 0.412 & 0.321 & 0.661 & 0.797 & 0.045 & 0.395 & 0.328 \\
\hline Poland & 0.565 & 0.030 & 0.775 & 0.234 & 0.498 & 0.677 & 0.078 & 0.778 & 0.257 & 0.518 & 0.606 & 0.060 & 0.772 & 0.290 & 0.468 \\
\hline Portugal & 0.435 & 0.280 & 0.400 & 0.354 & 0.303 & 0.643 & 0.235 & 0.444 & 0.360 & $0.339 !$ & 0.441 & 0.260 & 0.417 & 0.313 & 0.364 \\
\hline Romania & 0.588 & 0.071 & 0.707 & 0.387 & $0.372 !$ & 0.753 & 0.099 & 0.730 & 0.375 & 0.427 & 0.647 & 0.065 & 0.731 & 0.348 & 0.405 \\
\hline Slovak Republic & 0.600 & 0.135 & 0.553 & 0.316 & 0.372 & 0.781 & 0.219 & 0.562 & 0.383 & $0.393 !$ & 0.694 & 0.150 & 0.581 & 0.326 & 0.395 \\
\hline Slovenia & 0.353 & 0.142 & 0.522 & 0.243 & 0.380 & 0.576 & 0.211 & 0.525 & 0.311 & 0.414 & 0.451 & 0.173 & 0.491 & 0.244 & 0.393 \\
\hline Spain & 0.444 & 0.198 & 0.465 & 0.155 & 0.514 & 0.743 & 0.233 & 0.514 & 0.209 & 0.535 & 0.506 & 0.238 & 0.463 & 0.174 & 0.563 \\
\hline Sweden & 0.424 & 0.638 & 0.076 & 0.318 & $0.303 !$ & 0.665 & 0.491 & 0.165 & 0.264 & 0.406 & 0.437 & 0.449 & 0.122 & 0.229 & 0.402 \\
\hline Switzerland & 0.604 & 0.783 & 0.027 & 0.389 & 0.290 & 0.659 & 0.757 & 0.063 & 0.424 & 0.296 & 0.592 & 0.735 & 0.041 & 0.362 & $0.318 !$ \\
\hline Turkey & 0.681 & 0.205 & 0.558 & 0.457 & 0.291 & 0.839 & 0.210 & 0.650 & 0.410 & $0.388 !$ & 0.722 & 0.182 & 0.616 & 0.442 & 0.290 \\
\hline United Kingdom & 0.530 & 0.345 & 0.299 & 0.178 & 0.537 & 0.741 & 0.319 & 0.474 & 0.228 & 0.597 & 0.527 & 0.296 & 0.346 & 0.180 & 0.584 \\
\hline Average & 0.519 & 0.333 & 0.378 & 0.295 & 0.410 & 0.710 & 0.354 & 0.421 & 0.324 & 0.448 & 0.566 & 0.331 & 0.391 & 0.288 & 0.437 \\
\hline
\end{tabular}

Notes: Persistence of LOP deviations is defined here as the percentage of goods which remain on the same side of the distribution (either above or below zero) for the pair of years being compared in each case. The table presents this measure of persistence and correlations between the LOP deviations of the goods in different periods for 31 European countries. The sample is limited to tradeable goods. * income corrected persistence. In order to remove the income effect, we regress LOP deviations on income deviations, and then utilize the residuals i.e. the component of LOP deviations that excludes the effect of income for each country and year. ! the difference between persistence above and below is not significant at the $5 \%$ level of significance. We test for this using the proportions test for the null of equality of persistence above and below. 


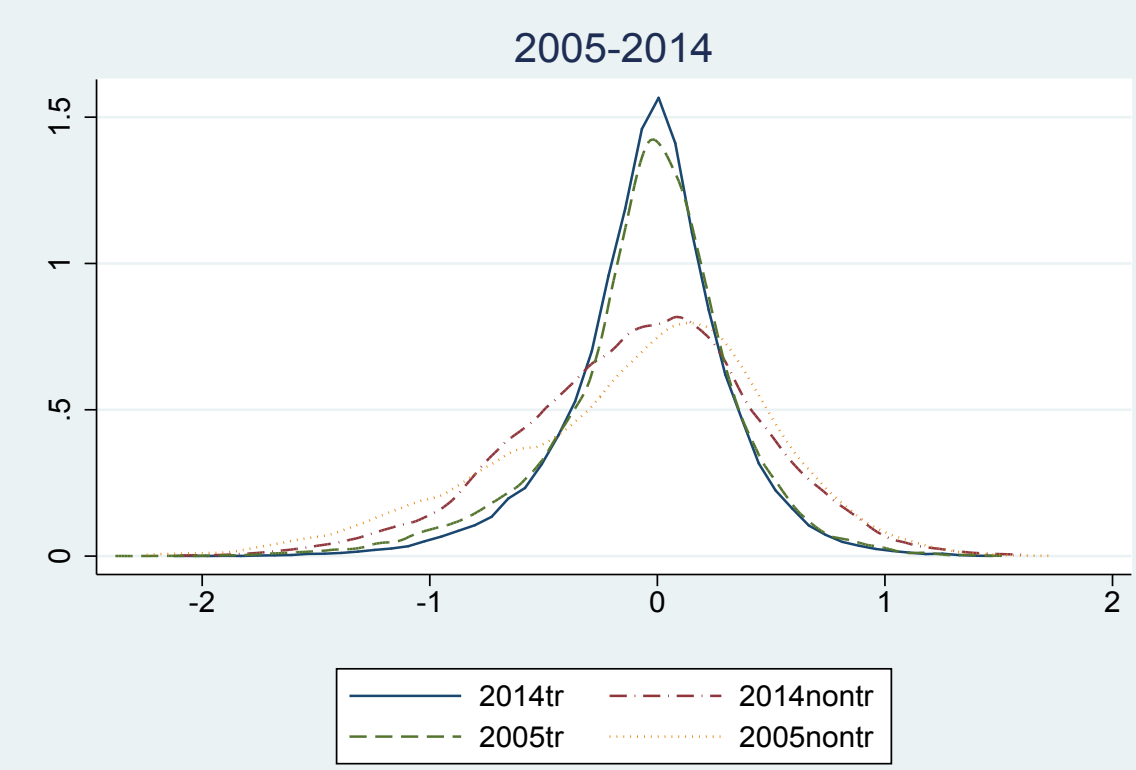

Figure 1: Empirical Distributions of LOP Deviations for 31-country sample for Tradeables (tr) and Non-tradeables (nontr).

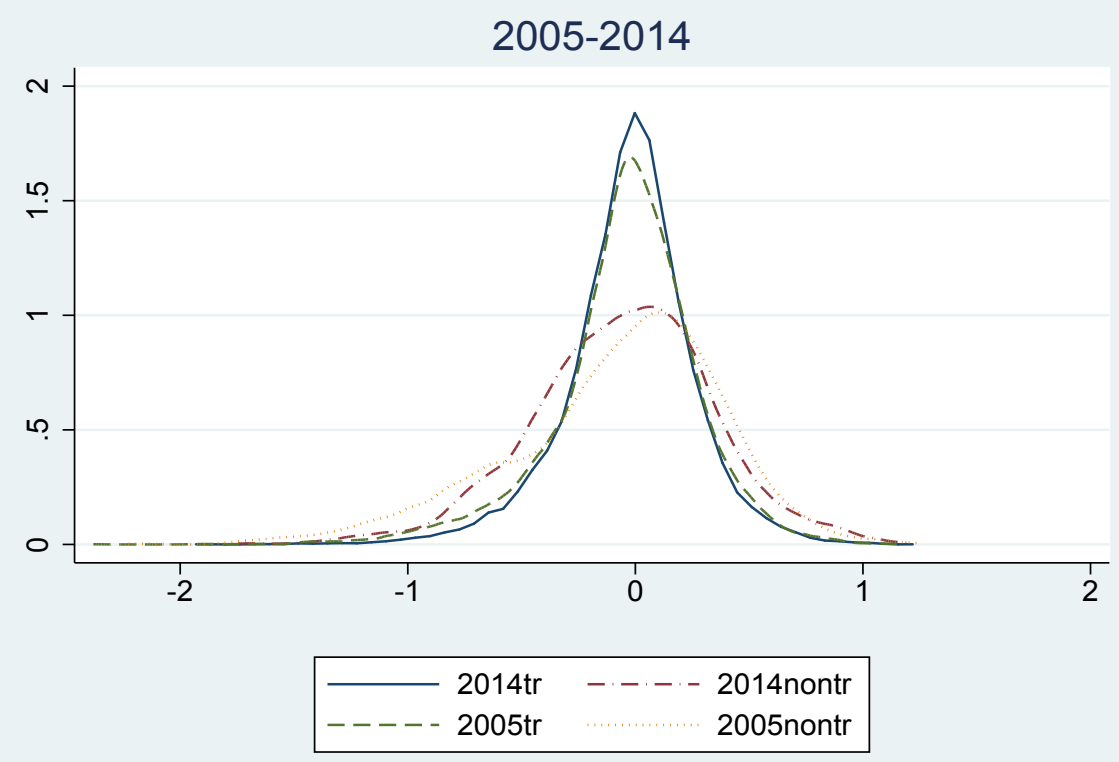

Figure 2: Empirical Distributions of LOP Deviations for 19-country sample for Tradeables (tr) and Non-tradeables (nontr). 

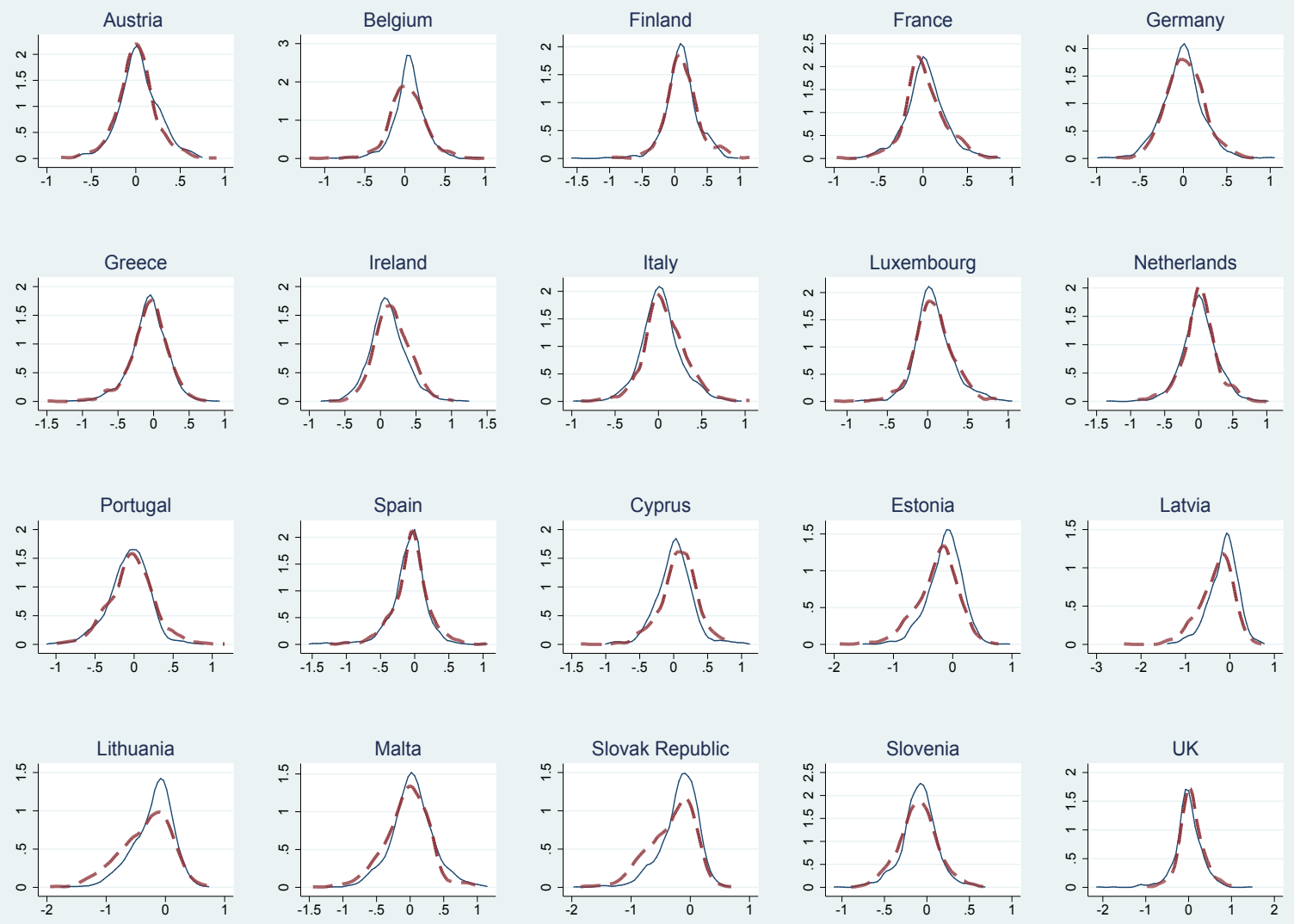

Figure 3: Empirical distributions of LOP deviations for the $19 \mathrm{EZ}$ countries and the UK for traded goods in 2014 (solid line) and 2005 (dash line). 

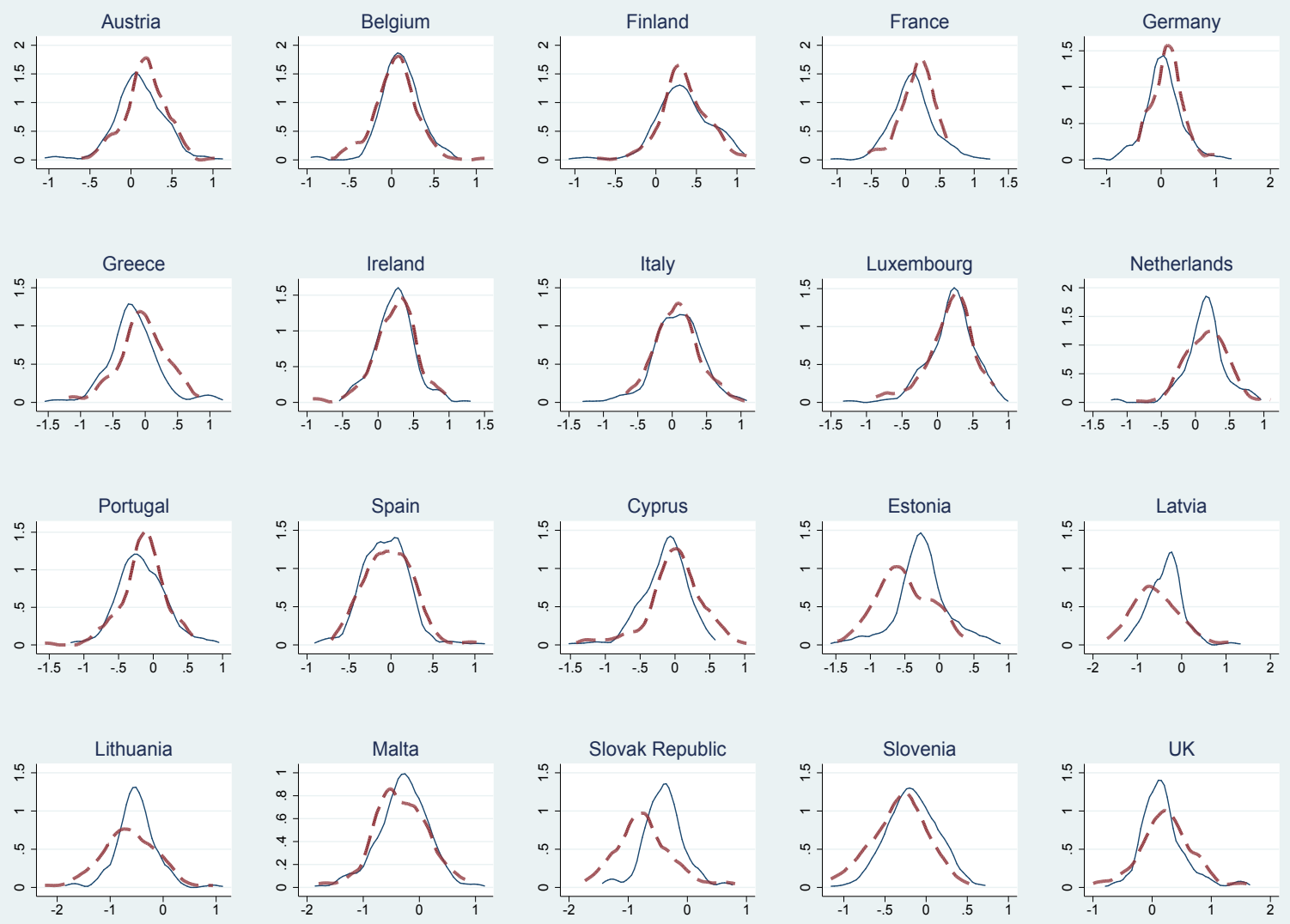

Figure 4: Empirical distributions of LOP deviations for the $19 \mathrm{EZ}$ countries and the UK for nontraded goods in 2014 (solid line) and 2005 (dash line)). 